\title{
KORELASI KOMPONEN KEBUGARAN JASMANI DENGAN PRESTASI BELAJAR PADA SISWA SD NEGERI 2 CIKERUH
}

\author{
Nurul Uyun ${ }^{1}$, Reni Farenia ${ }^{2}$, Tisnasari Hafsah ${ }^{3}$ \\ ${ }^{\mathbf{1}}$ Fakultas Kedokteran, Universitas Padjadjaran, Bandung, Indonesia, \\ ${ }^{2}$ Divisi Fisilogi, Fakultas Kedokteran, Universitas Padjadjaran, Bandung, Indonesia, \\ ${ }^{3}$ Departemen Ilmu Kesehatan Anak, RSUP Dr. Hasan Sadikin, Bandung, Indonesia.
}

\begin{abstract}
Physical fitness is a measure of health status as a basic physical condition of someone to perform daily activity. In this study, measurement pf physical fitness component consisted of cardiorespiratory endurance, body composition, muscular flexibility, and muscular strength. The purpose of this study is to know whether there is correlation between physical fitness and academic achievement. This study used observational analytical method with cross-sectional design. Data were collected by total sampling method, and there were eighty-two students from Cikeruh 2 Elementary School in Jatinangor from $4^{\text {th }}, 5^{\text {th }}$, and $6^{\text {th }}$ grade. Physical fitness assessment in this study consisted of step test, body mass index (BMI), push-up, and sit-up. Academic achievement data was collected from final examination result. Most students $(74,49 \%)$ has enough physical fitness. There is no significant correlation between physical fitness and academic achievement. Thus, based on this study, it was expected to conduct further study about other factors which affects the academic achievement.
\end{abstract}

Keywords: academic achievement, physical fitness, students

Korespondensi: Redaksi JIFO, Laboratorium Sentral, Universitas Padjadjaran, Jalan Raya Jatinangor KM. 21, Sumedang, Jawa Barat, Indonesia. E-mail: amrosdianto@ gmail.com 


\section{PENDAHULUAN}

Kebugaran jasmani adalah kemampuan untuk melakukan tugas seharihari secara sadar, menggunakan tenaga dan tidak membuat rasa lelah yang berlebihan serta masih memiliki tenaga untuk menikmati waktu luang. ${ }^{1} \quad$ Kebugaran jasmani juga dapat diartikan sebagai derajat status kesehatan seseorang sebagai kondisi fisik dasar untuk melakukan aktivitas sehari-hari. $^{2}$

Berbagai keuntungan yang dapat diperoleh pada fisik yang bugar yaitu mengurangi risiko terkena penyakit kardiovaskular, ${ }^{3}$ sindroma metabolik, ${ }^{4}$ diabetes, kanker kolon, dan obesitas, ${ }^{5}$ selain itu dapat meningkatkan fungsi sistem musculoskeletal dan juga berpengaruh terhadap kondisi psikologis, misalnya dapat mengurangi stress, depresi, rasa cemas, serta bisa meningkatkan kepercayaan diri. $^{6}$ Berbagai penelitian menunjukkan bahwa orang yang selalu menjaga kebugaran jasmani agar tetap dalam kondisi baik yaitu dengan olahraga

\section{METODE}

Penelitian dilaksanakan dalam rentang waktu bulan Oktober-September 2013 di SD Negeri 2 Cikeruh, Kecamatan Jatinangor, Kabupaten Sumedang.

Populasi penelitian adalah siswa SD Negeri 2 Cikeruh yang berusia 10-12 tahun. Jumlah sampel minimum yang dibutuhkan adalah 58 orang. Kriteria inklusi pada penelitian ini adalah siswa kelas 4-6 SD, bersedia untuk berpartisipasi dalam penelitian, tidak memiliki riwayat penyakit jantung, dalam kondisi yang sehat saat dilakukan tes, dan tidak memiliki gangguan penglihatan. Kriteria eksklusi pada penelitian ini adalah tidak mengikuti rangkaian tes dengan lengkap.

Penelitian ini merupakan penelitian analitik yang bermaksud untuk

\section{HASIL}

Penelitian ini dilaksanakan di SD Negeri 2 Cikeruh Kecamatan Jatinangor dari bulan September sampai bulan Oktober 2013. Sekolah ini dipilih secara acak. Sampel dalam penelitian adalah siswa SD berusia 10-12 tahun dari kelas teratur dan mengkontrol berat badan, memiliki usia yang panjang. Sebuah penelitian pada orang berusia 50-70 tahun, menunjukkan jumlah angka kematian 3 kali lebih sedikit daripada orang yang tidak fit. ${ }^{6}$ Seseorang dengan fisik yang bugar juga memiliki sedikit risiko terjadinya penyakit hipokinetik. Pada jaman sekarang dengan semakin meningkatnya inovasi dalam teknologi membuat manusia jarang melakukan aktivitas fisik, padahal aktivitas fisik dibutuhkan untuk memperoleh kebugaran jasmani. ${ }^{1}$

Banyak faktor yang memengaruhi proses dan hasil prestasi belajar anak di antaranya genetik, lingkungan, fasilitas sekolah, kurikulum, kompetensi guru, status ekonomi dan sosial, ${ }^{7}$ aktivitas fisik, ${ }^{8,9}$ status nutrisi, ${ }^{10}$ serta fungsi panca indera misalnya penglihatan. ${ }^{11}$

Penelitian mengenai hubungan antara kebugaran jasmani dengan prestasi belajar masih jarang dilakukan di Indonesia.

menganalisis korelasi antara komponen kebugaran jasmani dengan prestasi belajar siswa. Penelitian ini dilakukan dengan mengukur kebugaran jasmani siswa dan menilai prestasi belajar yang didapat dari rerata nilai rapor semester terakhir. Setelah memperoleh data, maka akan dianalisis korelasi antara kebugaran jasmani dengan prestasi belajar siswa.

Data yang telah terkumpul kemudian diolah dengan menggunakan program SPSS 15.0 for Windows. Untuk menentukan normalitas distribusi data, digunakan metode Kolmogorov-Smirnov. Jika data berdistribusi normal, maka dilakukan uji Pearson correlation, tetapi jika data tidak berdistribusi normal maka menggunakan Spearman-Rank correlation.

4-6. Total sampel berjumlah 82 orang. Karakteristik responden disajikan dalam tabel 1.

Tabel 1 menunjukkan karakteristik responden berdasarkan usia, komponen dari setiap tes kebugaran jasmani, serta 
penilaian prestasi belajar yang berdasarkan rerata nilai rapor. Penelitian ini menunjukkan bahwa tidak ada perbedaan yang besar antara rerata usia siswa laki- laki $(11,5 \pm 0,99)$ dan perempuan $(10,90 \pm$ 0,97). Anak laki-laki memiliki rerata berat badan yang lebih besar $(34,55 \pm 7,52)$ daripada anak perempuan $(28,98 \pm 6,92)$.

Tabel 1. Karakteristik responden

\begin{tabular}{|c|c|c|c|}
\hline Karakteristik & $\begin{array}{c}\text { Sampel } \\
\text { keseluruhan } \\
\mathbf{x} \pm \mathrm{SD}\end{array}$ & $\begin{array}{l}\text { Laki-laki } \\
\mathbf{x} \pm \mathrm{SD}\end{array}$ & $\begin{array}{c}\text { Perempuan } \\
\quad \mathbf{x} \pm \text { SD }\end{array}$ \\
\hline Usia (tahun) & $11,02 \pm 0,98$ & $11,15 \pm 0,99$ & $10,90 \pm 0,97$ \\
\hline Berat (kg) & $31,76 \pm 14,44$ & $34,55 \pm 7,52$ & $28,98 \pm 6,92$ \\
\hline Height $(\mathrm{cm})$ & $135,57 \pm 8,11$ & $\begin{array}{c}140,47 \pm \\
7,29\end{array}$ & $\begin{array}{c}139,96 \pm \\
7,29\end{array}$ \\
\hline $\begin{array}{l}\text { Indeks massa tubuh } \\
\left(\mathrm{kg} / \mathrm{m}^{2}\right)\end{array}$ & $13,91 \pm 3,97$ & $13,45 \pm 3,67$ & $14,38 \pm 4,25$ \\
\hline $\begin{array}{l}\text { Step test } \\
\text { (denyut/menit) }\end{array}$ & $128,33 \pm 17,80$ & $\begin{array}{c}127,68 \pm \\
15,90\end{array}$ & $\begin{array}{c}128,98 \pm \\
19,69\end{array}$ \\
\hline Sit-up (kali/menit) & $29,01 \pm 15,14$ & $\begin{array}{c}38,78 \pm \\
15,40\end{array}$ & $19,24 \pm 5,58$ \\
\hline Push-up (kali/menit) & $35,02 \pm 7,83$ & $37,68 \pm 8,36$ & $32,37 \pm 6,30$ \\
\hline $\begin{array}{l}\text { Skor kebugaran } \\
\text { jasmani }\end{array}$ & $12,5 \pm 2,09$ & $13,02 \pm 9,06$ & $11,9 \pm 2,13$ \\
\hline Rerata nilai rapor & $74,42 \pm 5,32$ & $74,05 \pm 5,31$ & $74,79 \pm 5,37$ \\
\hline
\end{tabular}

Tabel 2. Distribusi frekuensi kategori komponen kebugaran jasmani dan prestasi belajar

\begin{tabular}{|c|c|c|c|c|}
\hline Variabel & Kategori & $\begin{array}{c}\text { Laki-laki } \\
(n=41)\end{array}$ & $\begin{array}{c}\text { Perempuan } \\
(n=41)\end{array}$ & $\begin{array}{c}\text { Total } \\
(n=82)\end{array}$ \\
\hline \multirow[t]{5}{*}{ IMT } & Normal & $40(97,6 \%)$ & $37(90,2 \%)$ & $77(93,4 \%)$ \\
\hline & Overweight & $1(2,4 \%)$ & $4(9,8 \%)$ & $5(6,6 \%)$ \\
\hline & Obesitas 1 & 0 & 0 & 0 \\
\hline & Obesitas 2 & 0 & 0 & 0 \\
\hline & Obesitas 3 & 0 & 0 & 0 \\
\hline \multirow{7}{*}{ Step test } & Sangat & $5(12,2 \%)$ & & \\
\hline & bagus & & $16(39 \%)$ & $21(25,6 \%)$ \\
\hline & Bagus & 0 & $3(7,4 \%)$ & $3(3,6 \%)$ \\
\hline & Cukup & $5(12,2 \%)$ & $11(26,8 \%)$ & $16(19,6 \%)$ \\
\hline & Kurang & $3(7,4 \%)$ & 0 & $3(3,6 \%)$ \\
\hline & Sangat & $28(68,2 \%)$ & & \\
\hline & kurang & & $11(26,8 \%)$ & $39(47,6 \%)$ \\
\hline \multirow{7}{*}{ Sit-up } & Sangat & $14(34,2 \%)$ & & \\
\hline & bagus & & $1(2,4 \%)$ & $15(18,3 \%)$ \\
\hline & Bagus & $1(2,4 \%)$ & 0 & $1(1,2 \%)$ \\
\hline & Cukup & $8(19,5 \%)$ & 0 & $8(9,7 \%)$ \\
\hline & Kurang & $5(12,2 \%)$ & $2(4,8 \%)$ & $7(8,6 \%)$ \\
\hline & Sangat & $13(31,7 \%)$ & & \\
\hline & kurang & & $38(92,8 \%)$ & $51(62,2 \%)$ \\
\hline \multirow{7}{*}{ Push-up } & Sangat & $1(2,4 \%)$ & & \\
\hline & bagus & & $1(2,4 \%)$ & $2(2,3 \%)$ \\
\hline & Bagus & $8(19,6 \%)$ & $16(39 \%)$ & $24(29,3 \%)$ \\
\hline & Cukup & $16(39 \%)$ & $24(58,6 \%)$ & $40(48,8 \%)$ \\
\hline & Kurang & $16(39 \%)$ & 0 & $16(19,6 \%)$ \\
\hline & Sangat & 0 & & \\
\hline & kurang & & 0 & 0 \\
\hline
\end{tabular}


Tabel 3. Distribusi frekuensi kategori kebugaran jasmani dan prestasi belajar

\begin{tabular}{lcccc}
\hline Variabel & Kategori & Laki-laki & Perempuan & Total \\
\hline Kebugaran jasmani & Kurang & $12(29,3 \%)$ & $8(19,5 \%)$ & $20(24,4 \%)$ \\
& Cukup & $28(68,3 \%)$ & $33(80,5 \%)$ & $61(74,4 \%)$ \\
& Baik & $1(2,4 \%)$ & 0 & $1(1,2 \%)$ \\
\hline Prestasi belajar & $\geq$ rerata & $19(46,3 \%)$ & $17(41,5 \%)$ & $36(43,9 \%)$ \\
& $<$ rerata & $22(53,7 \%)$ & $24(58,5 \%)$ & $46(56,1 \%)$ \\
\hline
\end{tabular}

Karakteristik rerata tinggi badan anak laki-laki $(140,47 \pm 7,29)$ dan anak perempuan $(139,96 \pm 7,29)$ tidak menunjukkan perbedaan yang besar. Rerata indeks massa tubuh pada anak perempuan $(14,38 \pm 4,25)$ dengan anak laki-laki $(13,45 \pm 3,67)$ tidak menunjukkan perbedaan yang besar. Rerata denyut nadi setelah melakukan step test pada anak lakilaki $(127,68 \pm 15,90)$ dan perempuan $(128,98 \pm 19,69)$ menunjukkan perbedaan yang tidak terlalu besar.

Hasil tes sit-up pada anak laki-laki $(38,78 \pm 15,40)$ lebih besar dibandingkan dengan anak perempuan $(19,24 \pm 5,58)$. Hasil tes push-up pad anaak laki-laki $(37,68 \pm 8,36)$ juga menunjukkan hasil yang lebih besar dibandingkan dengan anak perempuan $(32,37 \pm 6,30)$, sedangkan rerata nilai rapor pada anak laki-laki $(74,05$ $\pm 5,31)$ dan perempuan $(74,79 \pm 5,37)$ tidak menunjukkan perbedaan yang besar.

\section{DISKUSI}

Penelitian ini bertujuan untuk mengetahui korelasi antara kebugaran jasmani dengan prestasi belajar pada siswa SD Negeri 2 Cikeruh.

Berdasarkan uji spearman, tidak ditemukan korelasi yang bermakna antara kebugaran jasmani dengan prestasi belajar $(\mathrm{p}>0,05)$ dan nilai koefisien korelasi $(\mathrm{r})=$ 0,209 . Hasil penelitian ini berbeda dengan penelitian sebelumnya yang menyatakan bahwa ada korelasi antara kebugaran jasmani dengan prestasi belajar. ${ }^{12,13,14} \mathrm{Hal}$ ini dapat terjadi karen aperbedaan metode yang digunakan untuk pengukuran

\section{KESIMPULAN}

Berdasarkan hasil penelitian dan pembahasan, dapat disimpulkan bahwa tidak terdapat korelasi yang signifikan
Tabel 2 menunjukkan bahwa sebagian besar siswa $(93,4 \%)$ memiliki IMT yang normal dan hanya sebagian kecil siswa $(6,6 \%)$ memiliki kelebihan berat badan. Hasil step test menunjukkan sebagian besar siswa $(47,6 \%)$ memiliki hasil yang sangat kurang. Tes sit-up juga menunukkan sebagian besar siswa $(62,2 \%)$ memiliki hasil yang sangat kurang. Untuk tes push-up, sebagian besar siswa $(48,8 \%)$ memiliki hasil yang cukup. Setelah dilakukan skoring, maka didapatkan kategori untuk kebugaran jasmani.

Tabel 3 menunjukkan bahwa sebagian besar siswa memiliki kebugaran jasmani yang cukup $(74,4 \%)$. Pengukuran prestasi belajar yang diperoleh dari rerata nilai rapor menunjukkan bahwa sebagian besar siswa $(56,1 \%)$ memiliki prestasi belajar kurang dari rerata.

kebugaran jasmani dan prestasi belajar, perbedaan ukuran sampel, serta perbedaan karakteristik dan latar belakang subjek penelitian.

Keterbatasan penelitian ini adalah pengambilan sampek dari satu sekolah saja sehingga kurang dapat memberikan gambaran pada populasi yang sebenarnya. Pada penelitian ini juga dapat terjadi ketidaksesuaian metode dan cara kategorisasi terhadap usia subjek. Selain itu, tidak ada observasi lebih lanjut mengenai faktor-faktor lain yang juga memengaruhi prestasi belajar.

antara kebugaran jasmani dengan prestasi belajar. 


\section{PENDANAAN}

Penelitian ini tidak didanai oleh sumber hibah manapun.

\section{KONFLIK KEPENTINGAN}

Tidak terdapat konflik kepentingan.

\section{DAFTAR PUSTAKA}

1. Giam DKC, Teh DKC. Sport medicine exercise and fitness. Singapore: PG Publishing; 1988. Hlm. 44.

2. Giriwijoyo S. Ilmu faal olahraga: Fungsi tubuh manusia pada olahraga. Edisi ke-1. Bandung: FPOK UPI; 2007. Hlm. 43, 45-68.

3. Malkova D, Gill JM. Physical activity, fitness, and cardiovascular disease risk in adults: Interactions with insulin resistance and obesity. Cardiovascular Disease. [Diakses pada tanggal 20 September 2013]. Tersedia dari: www.clinsci.org.

4. Laaksonen DE, Lakka HM, Salonen JT, Niskanen LK, Rauramaa R, Lakka TA. Low levels of leisure-time physical activity and cardiorespiratory fitness predict development of the metabolic syndrome. 2002;25(9);1612-8.

5. Guyton AC, Hall JE. Medical physiology. Edisi ke-11. Philadelphia: Elsevier Sunders; 2006.

6. US Department of Health and Human Services. Physical activity and health: A report of the surgeon general. Atlanta GA: US Department of Health and Human Services, Centers for Disease Control and Prevention.

7. Suryabrata S. Psikologi pendidikan, Edisi ke-1. Jakarta: Raja Grafinda Persada; 2003. Hlm. 78.

8. Coe DW, Pivarnik JM, Womack CJ, Reeves MJ, Malina RM. Effect of physical education and activity levels on academic achievement in children. Academic Achievement. [Diakses pada tanggal 19 Agustus 2013]. Tersedia dari: www.acsm-msse.org.

9. Trudeau F, Shephard RJ. Physical education, school physical activity, school sports, and academic performance. International Journal of Behavioral Nutrition and Physical Activity. 2008;5(1):10-22.

10. Sabia JJ. The effect of body weight on adolescent academic performance. Southern Economic Journal. 2007; 73(4):871-900.

11. Maples WC. Visual factor that significantly impact academic performance. Optometry. 2003;74(1):35-49.

12. Grissom JB. Physical fitness and academic achievement. Journal of Exercise Physiology. 2005;8(1):1125.

13. Dwyer T, Sallis JF, Blizzard L, Lazarus R, Dean K. Relation of academic performance to physical activity and fitness in children. Pediatric Exercise Science. 2001;13:225-37.

14. Sayers BM, Farley RS, Fuller DK, Morgan DW, Caputo JL. Physical fitness and academic achievement in elementary school children. Journal of Physical Activity and Health. 2009;6:99-104. 